\title{
EUCALYPTUS CORDATA SUBSP. QUADRANGULOSA (MYRTACEAE), A NEW TAXON OF RESTRICTED DISTRIBUTION FROM SOUTHERN TASMANIA
}

\author{
by Dean Nicolle, Brad M. Potts and Gay E. McKinnon
}

(with one text-figure and four plates)

\begin{abstract}
Nicolle, D., Potts, B.M. \& McKinnon, G.E. 2008 (28:xi): Eucalyptus cordata subsp. quadrangulosa (Myrtaceae), a new taxon of restricted distribution from southern Tasmania. Papers and Proceedings of the Royal Society of Tasmania 142(2): 71-78.

https://doi.org/10.26749/rstpp.142.2.71 ISSN 0080-4703. Currency Creek Arboretum, 15 Rousillion Promenade, Old Reynella, South Australia 5161, Australia $\left(\mathrm{DN}^{*}\right)$. School of Plant Science and Cooperative Research Centre for Forestry, University of Tasmania, Private Bag 55, Hobart, Tasmania 7001, Australia (BMP, GEMcK). *Author for correspondence. Email: Dean.Nicolle@dn.com.au

Eucalyptus cordata subsp. quadrangulosa is described to accommodate western populations of the species, and differs from the typical subspecies most conspicuously in the quadrangular branchlets, and also in the larger and more pointed juvenile leaves, the more flattened peduncles, the larger bi-ribbed flower buds, and the larger fruits. The quadrangular branchlets of the new subspecies are unique in $E$. ser. Orbiculares. The new subspecies occurs to the west of, and largely disjunct from, eastern E. cordata, and tends to occupy cooler and wetter sites. Some morphologically and geographically intermediate populations are known. Both subspecies of $E$. cordata are of restricted distribution and are known from relatively few, disjunct and generally numerically small populations, and as such are under threat from various natural and human-induced influences. The newly described subsp. quadrangulosa is commonly cultivated in cool climates as an ornamental tree for its silvery foliage. A key to $E$. ser. Orbiculares, and a distribution map and photographs of representative types of $E$. cordata are presented.
\end{abstract}

Key Words: Eucalyptus cordata, Eucalyptus cordata subsp. quadrangulosa, silver gum, Orbiculares, Tasmania, new subspecies.

\section{INTRODUCTION}

Eucalyptus cordata Labill. (Heart-leaved Silver Gum) is a woody shrub or tree restricted to southeastern Tasmania, well-known for its ornamental appeal in cultivation and because of its rarity in the wild. The species is cultivated for its crown of silvery juvenile foliage in cooler climates in southeastern Australia, and particularly in southern Tasmania, as well as in overseas locations including the United Kingdom and New Zealand. The species has long been recognised as one of the rarer eucalypts (Pryor 1981) and is considered rare and inadequately reserved using the criteria of Briggs $\&$ Leigh (1996). While it does not qualify for listing under the Tasmanian Threatened Species Protection Act 1995, it is a Priority species for conservation under the Tasmanian Regional Forest Agreement.

Despite its naturally restricted distribution, E. cordata was first described by Jacques-Julien de Labillardière in 1806 from specimens he collected in 1793 while chief scientist aboard the French expedition ships La Recherche and L'Espérance. Potts (1988), in an historical account of the type locality of $E$. cordata, demonstrated that Labillardière certainly collected the type specimens from Penguin Island while the expedition was anchored in Adventure Bay off Bruny Island. Following the type collection, the species was rarely collected in the wild, despite being well-known from the Wellington Range area. Only in the past few decades has the species been more frequently collected and its distribution better known, mainly through the work of Potts $(1988,1989)$.

Population variation within $E$. cordata has been studied in detail by Potts (1989), although several more populations of the species have been discovered since that study at locations including the Meehan Ranges, Mount Hull and Kettering. In addition to a number of practical recommendations to conserve the genetic diversity in E. cordata, Potts (1989) proposed a taxonomic revision of the species and the recognition of two subspecies, which is formally adopted here. Subsequent flora treatments including the Tasmanian eucalypts have followed Potts (1989) in recognising the dimorphic and geographically-based variation within $E$. cordata, e.g., Williams \& Potts (1996), Brooker \& Kleinig (1999, 2006), Brooker et al. (2002), Nicolle (2006) and Slee et al. (2006).

Eucalyptus cordata is currently classified in E. ser. Orbiculares (Brooker 2000), which is distinguished within the genus by the combination of the following characteristics (amended from Brooker 2000):

E. subgen.Symphyomyrtus (Schauer) Brooker-cotyledons folded in seeds; flower buds bi-operculate; seeds with a ventral or terminal hilum; seed coat formed from both integuments.

E. sect. Maidenaria L.D. Pryor \& L.A.S. Johnson ex Brooker-Cotyledons bilobed; inflorescences axillary; anthers versatile; seeds with a ventral hilum; adult leaves moderately reticulate and with island and intersectional oil glands.

E. subsect. Euryotae Brooker - Juvenile leaves sessile and opposite for many pairs; style long; adult leaves with oil glands; fruit disc and valves usually prominent.

E. ser. Orbiculares Brooker \&Slee-Juvenile leaves orbicular, entire or broadly crenulate, usually waxy and opposite for many pairs (and often persistent in mature crown); mature crown often greyish; inflorescences 3-flowered; flower buds rhomboidal.

Brooker (2000) recognised ten species in E. ser. Orbiculares. The series is distributed in the cooler areas of southeastern Australia, from the Blue Mountains in the central tablelands of New South Wales southwards, with greatest taxonomic diversity in southeastern Tasmania. All but one species ( $E$. perriniana F.Muell. ex Rodway) are endemic to either the Australian mainland or Tasmania.

Brooker (2000) included E. chapmaniana Cameron within $E$. ser. Orbiculares, but we do not include this species in the series here, preferring to include it in $E$. ser. Viminales Blakely (also with E. smithii R.T.Baker, E. badjensis Beuzev. 
\& M.B.Welch and E. kartzoffiana L.A.S.Johnson \& Blaxell; these three species together forming $E$. ser. Compactae Brooker of Brooker 2000). E. chapmaniana differs from the remainder of $E$. ser. Orbiculares in the consistently forest tree habit, rough bark on the trunk, non-persistence of juvenile leaves (crown of lanceolate adult leaves), and small buds and fruits with a relatively broad, ascending disc. These characteristics are in common with other taxa of E. ser. Viminales.

Eucalyptus ser. Orbiculares can be further divided into two distinct groups (excluding E. cordata), namely, those taxa with sessile buds and fruits which occur on mainland Australia (with three of the four taxa endemic there), and those taxa with pedicellate buds and fruits which are endemic to Tasmania. E. cordata appears to fit most comfortably with the mainland taxa on morphological grounds, but the biogeography of the species suggests otherwise. Furthermore, a recent analysis of all Tasmanian taxa of E. sect. Maidenaria using multiple nuclear DNA markers (McKinnon et al. 2008) found that E. cordata was closely related to all other endemic Tasmanian species of $E$. ser. Orbiculares. None of these species was in the same genetic group as $E$. perriniana (the type species of $E$. ser. Orbiculares) which occurs both on mainland Australia and in Tasmania, raising the possibility that mainland and endemic Tasmanian taxa currently classified into $E$. ser. Orbiculares may represent different evolutionary lineages that have converged in morphology.

\section{KEY TO THE TAXA OF E. SER. ORBICULARES}

1. Buds and fruits sessile or nearly so 2

1. Buds and fruits pedicellate 7

2. Juvenile leaves connate. E. perriniana

2. Juvenile leaves free 3

3. Mature crown composed of lanceolate, petiolate adult leaves ........................................ 4

3. Mature crown composed mostly of rounded to ovate, sessile juvenile leaves $\ldots \ldots \ldots \ldots \ldots \ldots \ldots \ldots \ldots . \ldots$

4. Fruits campanulate and with a flared rim

4. Fruits cupular to cylindrical and lacking a flared rim .................................. E. glaucescens

5. Juvenile leaves firm, not cordate (rounded), 20-50 mm long; fruit 5-10 mm long ........... E. pulverulenta

5. Juvenile leaves lax, usually cordate, $15-95 \mathrm{~mm}$ long; fruit 7-13 mm long 6

6. Branchlets terete in transverse section ....................... E. cordata subsp. cordata

6. Branchlets quadrangular in transverse section ......... ..................... E. cordata subsp. quadrangulosa

7. Peduncles long and down-curved; fruits urceolate ... ....................................... E. urnigera

7. Peduncles held erect; fruits cylindrical to barrel-shaped to slightly urceolate....
8. Operculum slightly wider than hypanthium at join; coastal ............................... E. morrisbyi

8. Operculum equal in width to hypanthium at join; alpine

9. All parts non-waxy; adult leaves green ... E. archeri

9. At least juvenile leaves waxy; adult leaves blue-green

10. Fruits usually non-waxy and barrel-shaped ........ E. gunnii subsp. gunnii

10. Fruits waxy and barrel-shaped to urceolate ........ E. gunnii subsp. divaricata

\section{TAXONOMY}

\section{Eucalyptus cordata Labill., Nov. Holl. PI. 2 , 13 (1806).}

Type

"capite van-Dieman" [Van Diemens Land], J.J.H. Labillardière s.n. (holo: FI; iso: BM, G, L, MEL).

The type locality has commonly (and erroneously) been cited as Recherche Bay (near South East Cape), which appears to have stemmed from an erroneous citation of the species at Recherche Bay by Hooker (1860) and subsequent citations of the species at that locality by other authors until at least 1988 (Chippendale 1988). Potts (1988) demonstrated that Labillardière certainly collected the type specimens from Penguin Island, just off Bruny Island, where the species has been more recently verified (Potts 1988). The species has not been verified from Recherche Bay, with the nearest confirmed population being at Penguin Island, $45 \mathrm{~km}$ to the northeast.

\section{Description}

Scraggy shrub or tree up to $25 \mathrm{~m}$ tall, usually several to multi-stemmed. Lignotuber present. Bark usually smooth throughout, grey to orange-tan over pale grey to tan, decorticating in strips and ribbons. Rough bark sometimes present on the lower trunks of larger trees (in subsp. quadrangulosa), moderately fissured, grey. Branchlets lacking pith glands. Branchlets, leaves, flower buds and fruits waxy, at least when young. Plant usually reproductively mature in juvenile leaf phase. Juvenile leaves amplexicaul, free (not connate), broadly crenulate (scalloped) or sometimes entire, waxy, dull, greyish. Inflorescences axillary, unbranched, held erect, 3-flowered. Operculum scar present. Stamens mostly inflexed, all fertile; anthers cuboid to oblong, versatile, dorsifixed, dehiscing by longitudinal slits. Ovules in 4-6 vertical rows. Flowers white. Seeds grey to black, compressed ovoid, finely lacunose.

\section{Discussion}

Eucalyptus cordata is distinguished within $E$. ser. Orbiculares by the following combination of characters: plant reproductively mature in juvenile leaf phase and rarely producing adult leaves; branchlets, leaves, buds and fruits waxy, at least while young; juvenile leaves free (not connate), often broadly crenulate (scalloped); inflorescences pedunculate and held erect; pedicels absent or to $2 \mathrm{~mm}$ long; fruits (truncate-globose to) cupular (to shortly barrel-shaped). 
Two geographically disjunct subspecies are recognised in $E$. cordata, differing from one another most notably in branchlet morphology, but also in habit characteristics and vegetative and reproductive morphology. Little weight has been placed on habit differences in the recognition of the two subspecies. There is a large degree of overlap in habit characteristics between the two subspecies, and habit is likely to be at least partly environmentally determined within the species, with varying site conditions and fire histories at each population. In addition to the morphological distinctions, the two subspecies also differ in habitat preferences and flowering times. A few populations suspected to be intergrades between the two subspecies are known in geographically intermediate regions and are described below. Neither subspecies of $E$. cordata has been confirmed from Meredith Tier (near Swansea; north of the verified distribution of E. cordata), and hybrid swarms involving E. barberi L.A.S.Johnson \& Blaxell from this locality most likely involve E. gunnii Hook.f. (McEntee et al. 1994), which occurs approximately $7 \mathrm{~km}$ away (Potts 1988).

Representative photographs of the branchlets, leaves, buds and fruits of the two subspecies, which readily illustrate the morphological differences between them, can be found in Potts (1989), Williams \& Potts (1996), Nicolle (2006) and Wiltshire \& Potts (2007).

\section{Eucalyptus cordata Labill. subsp. cordata}

Distinguished from subsp. quadrangulosa most conspicuously by the terete branchlets (pl. 1; square to winged in transverse section in subsp. quadrangulosa), and also in the consistently

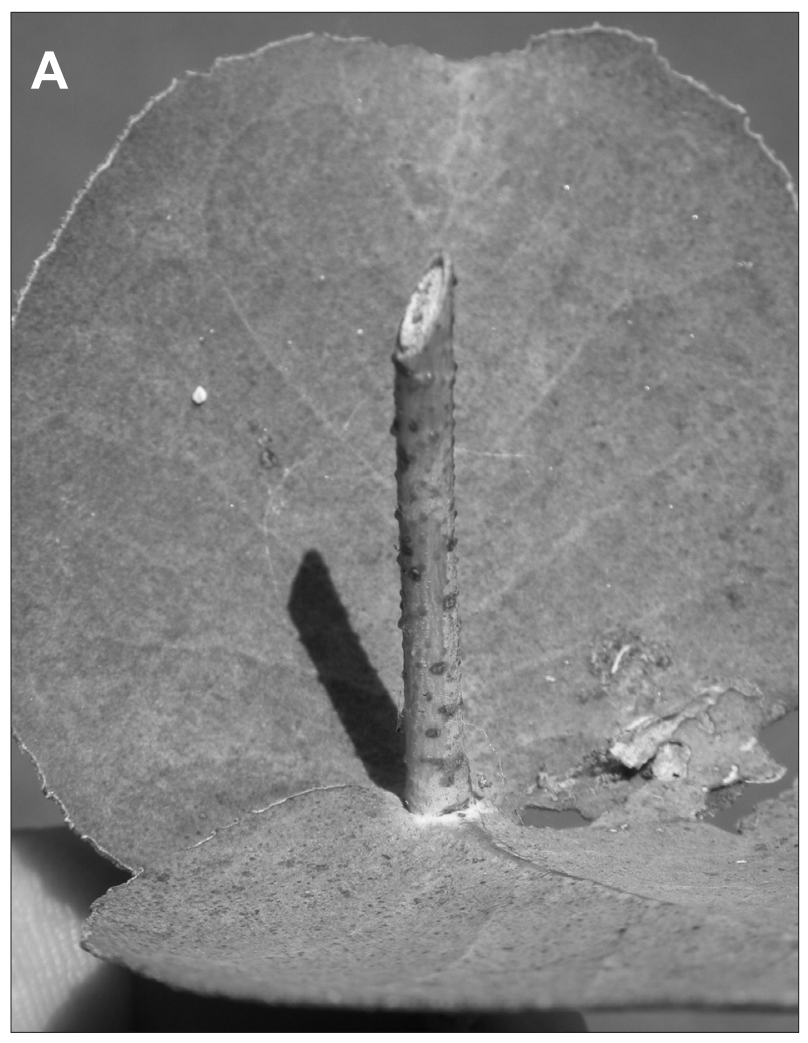

scraggy under-shrub habit, smaller and more rounded juvenile leaves, the terete or less prominently flattened peduncles, the smaller non-ribbed flower buds, and the smaller fruits.

\section{Description}

Scraggy shrub up to $6 \mathrm{~m}$ tall, usually multi-stemmed; often growing as an understorey shrub to taller forest or woodland eucalypt species (pl. 2). Branchlets rounded in transverse section, often conspicuously minutely warty, variably waxy. Juvenile leaves opposite, sessile and amplexicaul, cordate to rounded, usually entire, (15-) 30-70 (-80) mm long x (15-) 25-60 (-70) mm wide, variably waxy, slightly discolorous to concolorous, dull, grey-green. Intermediate leaves opposite to sub-opposite, petiole to $12 \mathrm{~mm}$ long, lamina ovate, longer and relatively narrower than juvenile leaves. Adult leaves rarely developed, sub-opposite, petiole to $15 \mathrm{~mm}$ long, lamina lanceolate, to $90 \mathrm{~mm}$ long, variably waxy, concolorous, dull, grey-green. Peduncles 2-12 (-15) mm long, terete to slightly flattened. Pedicels absent or to $2 \mathrm{~mm}$ long (especially the middle bud/fruit), terete to angular. Flower buds $7-11 \mathrm{~mm}$ long x 4.5-7 mm wide, waxy; hypanthia cupular; opercula smooth, rounded to pileate, $2.5-5 \mathrm{~mm}$ long. Fruits cupular to shortly barrel-shaped, 7-10 (-11) mm long x 6-10 (-12) $\mathrm{mm}$ wide, waxy at first; disc descending; valves 3 or 4 , to rim level.

\section{Specimens examined}

TASMANIA: $1 \mathrm{~km}$ NW of Jacob Hill, Sandpit River area, undated, S. Harris s.n. (HO); Brown Mountain [probably Mount Brown], Port Arthur, Sept. 1937, R.G. Brett s.n. (HO) $[E$. cordata has not been found on Mount Brown

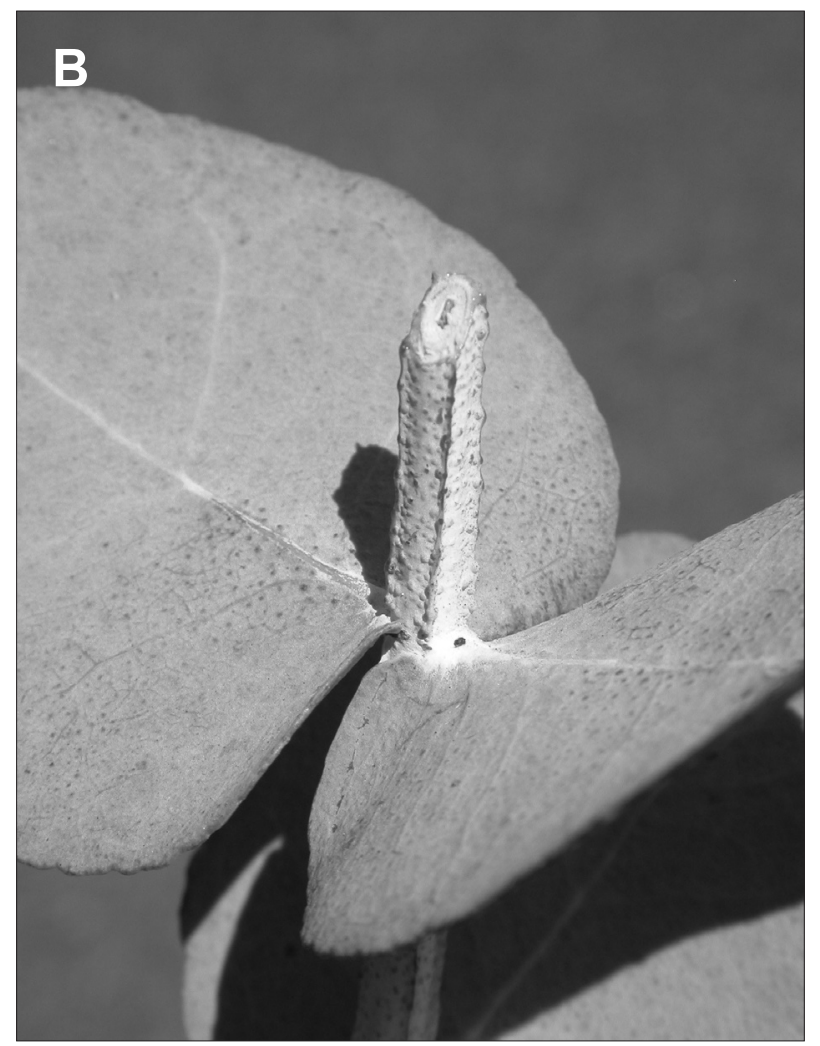

PLATE 1

Branchlets from cultivated eight-year-old Eucalyptus cordata growing at Currency Creek Arboretum, South Australia.

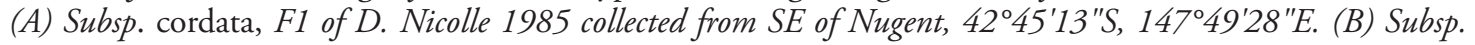
quadrangulosa, F1 of D. Nicolle 1979 collected from Mt Lloyd, SW of New Norfolk, 42 50'11"S, 146 56'54"E. 


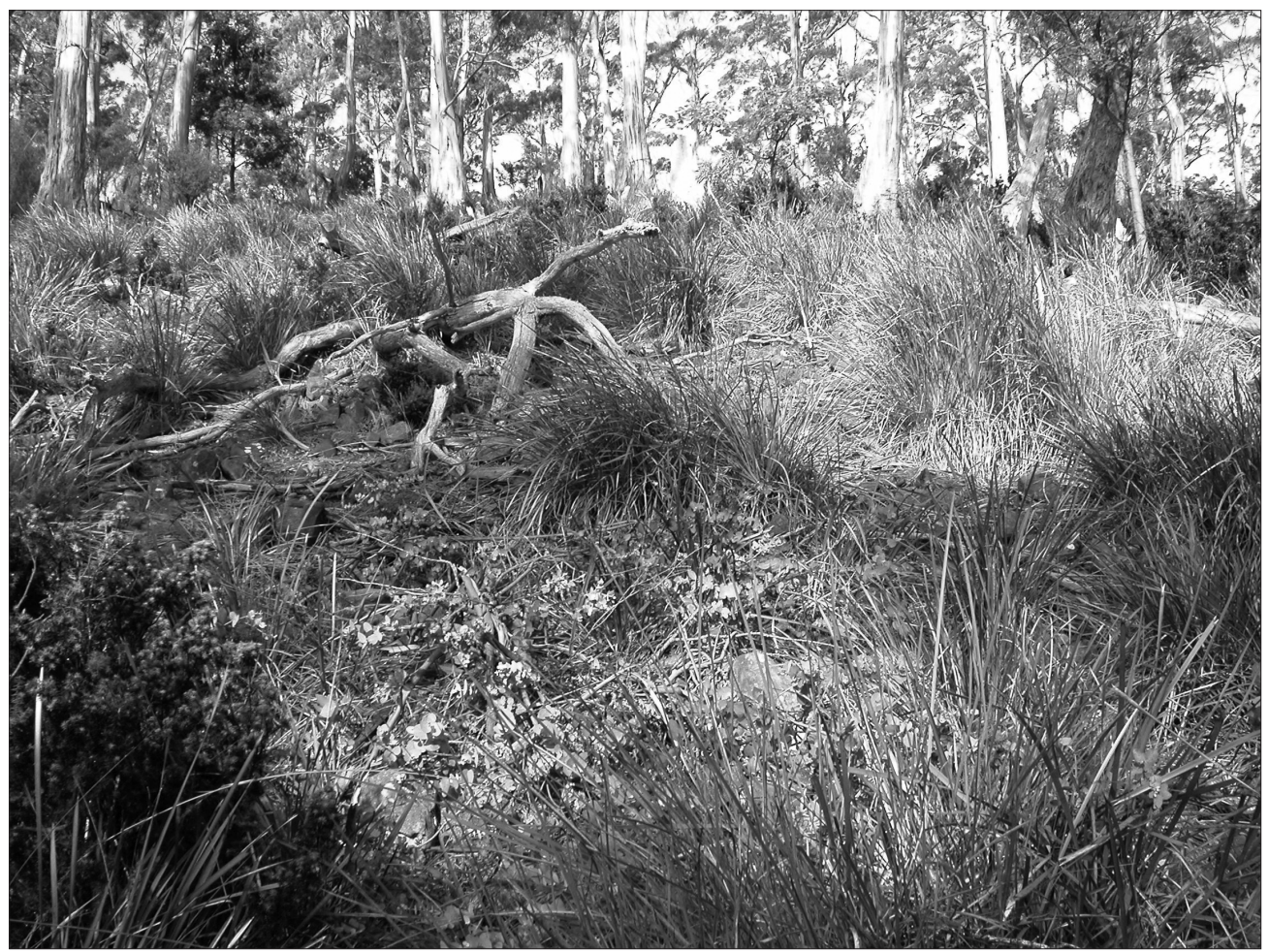

\section{PLATE 2}

Habit and habitat of Eucalyptus cordata subsp. cordata (Hospital Creek, north of Kellevie). Note that $\mathrm{E}$. cordata is the very low scraggy shrubs in the centre foreground; larger eucalypts in the background are mainly E. pulchella, with some E. globulus and E. obliqua. despite extensive searching - Potts 1989 - and this locality is either an erroneous rendering of Brown Mountain near Runnymede, where E. cordata aff. ssp. cordata is known to occur, or the population is now extinct]; Nelsons Tier, Feb. 1941, R.G. Brett s.n. (HO); Summerleas Road, Sept. 1942, R.G. Brett s.n. (HO); banks of Prosser River, on hill, May 1945, R.G. Bretts.n. (HO); Wielangta, May 1945, R. G. Brett 10 (HO); SE Maria Island. Near (slopes of) Perpendicular Mountain, April 1976, A. Moscal s.n. (HO); Trig Point, Hellfire Bluff, 3 Nov. 1979, M.J. Brown 497 (HO); Maria Island, Perpendicular Mountain, 18 June 1979, A. Moscal 55 (AD); Chimney Pot Hill, on telecom access rd, $2 \mathrm{~km}$ from Ridgeway Rd junction, 9 Jan. 1980, A.M. Grey 471 (HO); Hospital Creek, 28 Nov. 1980, F. Duncan s.n. (HO); Burdens Razorback, N of Kellevie, 31 Oct. 1983, A. Moscal 3861 (HO); Cape Queen Elizabeth, North Bruny Island, 31 March 1986, A.M. Buchanan 8379 (CANB, HO, MEL, NSW); Penguin Island, on $S$ cliff slope (facing Fluted Cape), Nov. 1986, B.M. Potts PI4, PI5, PI7, PI8 \& PI9(HO); Pony Bottom Creek, 18 Dec. 1987, B. Potts s.n. (HO); Back Run Hills, 12 August 1993, B. Warren s.n. (HO); Meehan Range, above mudstone cliffs at end of track branching from main ridge road, 21 Sept. 1997, B. Potts.n. (CANB, HO, NSW); Meehan Range, SRA - Redgate Section, 8 August 1996, K. Ziegler s.n. (HO); SE of Nugent, $42^{\circ} 45^{\prime} 13^{\prime \prime S}, 147^{\circ} 49^{\prime} 28^{\prime \prime E}$, 24 Feb. 1997, D. Nicolle 1985 (AD, CANB); Hellfire Bluff, 27 Sept. 2003, K. Felton s.n. (HO); summit of Perpendicular Mountain, Maria Island, 11 Oct. 2003, K. Felton s.n. (HO); Penguin Island, off Grass Point, South Bruny Island, 28 Feb. 2004, A.M. Grey 1338 (HO); hill just $S$ of Whittens Road, $S$ of Kettering, 21 Dec. 2004, A. Welling s.n. (HO); Ragged Tier, N of Bream Creek, 4247'32"S, $147^{\circ} 50^{\prime} 44^{\prime \prime E}, 7$ May 2005, D. Nicolle 4931 (AD).

\section{Distribution and habitat}

Endemic to southeastern Tasmania, where it occurs east from Mt Grosse near Middleton and south from Bluestone
Tier near Triabunna, including Bruny and Maria islands and the Tasman Peninsula, over a maximum linear range of $110 \mathrm{~km}$ (fig. 1).

Eucalyptus cordata subsp. cordata is known from approximately 27 very scattered populations. The subspecies grows from near sea level to $470 \mathrm{~m}$ altitude in dry or seasonally drought-stressed sclerophyll forest, woodland or coastal scrub, on moderately well-drained skeletal clay-loams, often as an under-storey shrub to larger eucalypt species such as E. globulus Labill., E. obliqua L'Her., E. viminalis Labill. and most commonly E. pulchella Desf. (pl. 2). In coastal sites the subspecies may occur in small, near pure stands or with Allocasuarina verticillata (Lam.) L.A.S.Johnson. The subspecies tends to occur at lower altitudes having a lower and less reliable rainfall and on better-drained soils than those occupied by subsp. quadrangulosa.

An atypical population of E. cordata subsp. cordata occurring on Brown Mountain near Runnymede develops adult foliage and may have some affinities to E. urnigera Hook.f. (Potts 1988). The population occurs on a poorly drained site at relatively high altitude $(710 \mathrm{~m})$ near an outlying population of E. coccifera Hook.f. (Potts 1989), a habitat otherwise atypical for E. cordata subsp. cordata.

\section{Conservation status}

Approximately 27 populations consisting of an estimated 4000-5000 individual plants are known. The largest populations occur at Corbetts Lookout (near Kellevie - c. 1000 individuals), Cape Queen Elizabeth (Bruny Island c.1000 individuals) and Perpendicular Mountain (Maria Island-500+ individuals), while most populations generally have less than several hundred individual plants (Potts 1988, 1989).

Six populations occur in reserves, namely, the populations at Perpendicular Mountain (Maria Island National Park), Hellfire Bluff (Cape Bernier State Reserve), Hospital Creek (Hospital Creek Nature Reserve), Meehan Range (Meehan 
FIG. 1- Map of southeastern Tasmania, indicating the distribution of Eucalyptus cordata.

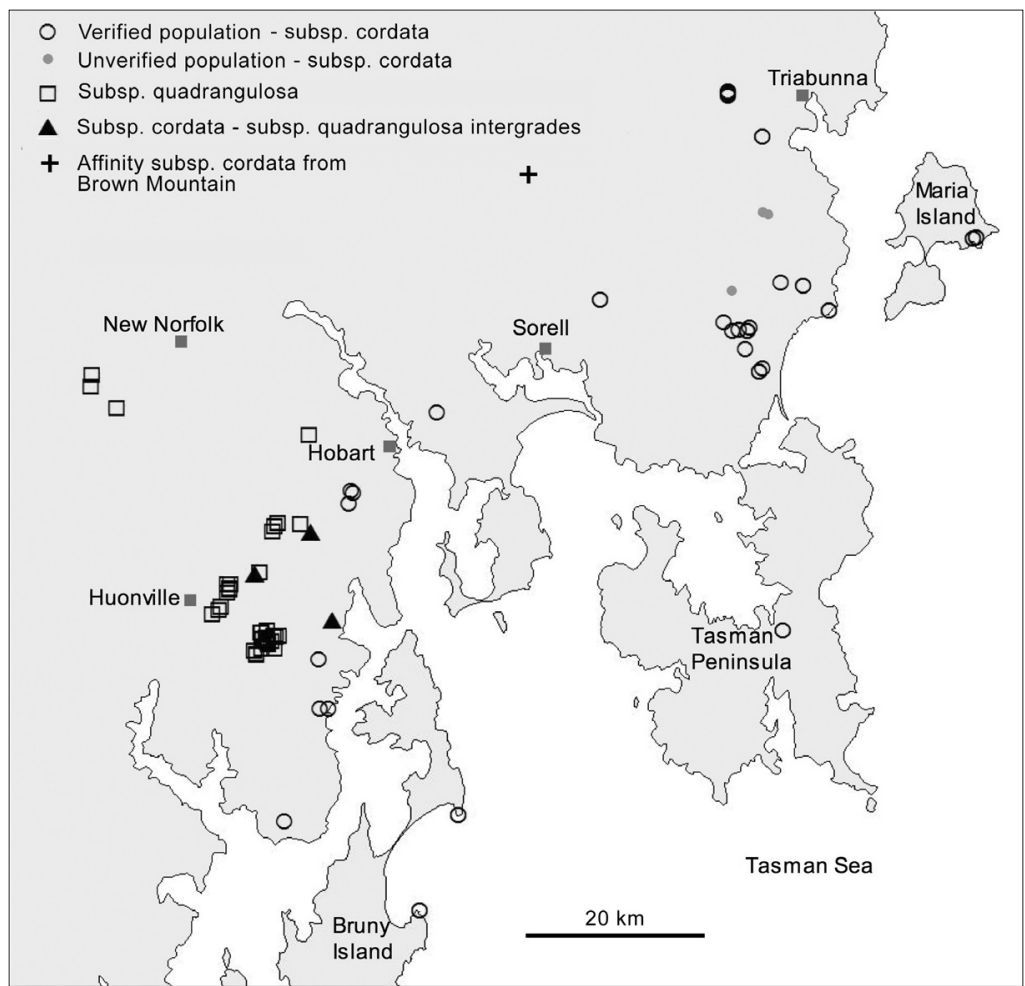

Range National Recreation Area), Cape Queen Elizabeth (Bruny Island Neck Game Reserve) and Penguin Island (South Bruny National Park). Other populations occur in state forest or on privately-owned land.

\section{Discussion}

Eucalyptus cordata subsp. cordata is most readily distinguished from the Tasmanian endemics E. archeri Maiden \& Blakely, E. gunnii, E. morrisbyi Brett and E. urnigera by the retention of largely juvenile leaves in the mature crown, although a number of other vegetative and reproductive morphological characteristics also distinguish $E$. cordata subsp. cordata from these taxa. From E. perriniana (the only E. ser. Orbiculares taxon to occur naturally both on the mainland and in Tasmania), E. cordata subsp. cordata differs most conspicuously in the non-connate juvenile leaves forming the crown of the plant. E. cordata subsp. cordata may be confused with the mainland species E. pulverulenta Sims, which occurs as a few very scattered populations between Lithgow and Bombala in New South Wales. E. cordata subsp. cordata differs from $E$. pulverulenta in the generally larger, more lax, cordate, and often broadly crenulate (scalloped) juvenile leaves, the usually warty juvenile branchlets, and the fruits with a more descending disc and less exsert valves.

A hybrid swarm involving E. cordata subsp. cordata and another eucalypt, putatively $E$. barberi, has been recorded at the Pony Bottom Creek population of the former, at the northern end of its distribution (Potts 1989, McEntee et al. 1994). Populations of E. cordata subsp. cordata at Prosser River and Hellfire Bluff may have genetic introgression from surrounding E. viminalis, as indicated by seedling studies (Potts 1989).

\section{Eucalyptus cordata subsp. quadrangulosa D. Nicolle, B.M. Potts \& G.E. McKinnon subsp. nov.}

= Eucalyptus cordata subsp. "western" (Nicolle 2006: 106).

\section{Type}

Snug Plains, 15 April 1979, A.M. Grey 357 (holo: HO; iso: CANB) (pl. 3).

A subspecie typica ramuli quadrangulatis, foliis juvenilibus majoribus et plus acutis, pedunculis plus saepissime applanatis, alabastris fructibusque bialatis et majoribus differt.

Distinguished from the typical subspecies most conspicuously by the quadrangular branchlets (pl. 1), and also in the commonly larger habit, the larger and more pointed juvenile leaves, the more commonly flattened peduncles, the larger bi-ribbed flower buds, and the larger bi-ribbed fruits.

\section{Description}

Bushy shrub or tree, often several-stemmed, 2-25 m tall (pl. 4). Branchlets quadrangular to 4-winged in transverse section, usually waxy. Juvenile leaves opposite, sessile and amplexicaul, cordate to ovate to broadly elliptical, entire to broadly crenulate (30-) 45-90 (-100) mm long x (35-) 40-65 (-95) mm wide, usually waxy, slightly discolorous to concolorous, dull, grey-green. Intermediate leaves subopposite, becoming petiolate, lamina elliptical to ovate, longer and relatively narrower than juvenile leaves. Adult leaves occasionally developed in taller trees, disjunct, petiole to 30 $\mathrm{mm}$ long, lamina lanceolate, to $180 \mathrm{~mm}$ long $\mathrm{x} 70 \mathrm{~mm}$ wide, variably waxy, concolorous, dull, grey-green. Peduncles 5-12 $\mathrm{mm}$ long, angular to flattened. Pedicels absent or to $1 \mathrm{~mm}$ long (especially the middle bud/fruit). Flower buds 10-12 (-13) mm long x 7-10 mm wide, waxy; hypanthia cupular, 


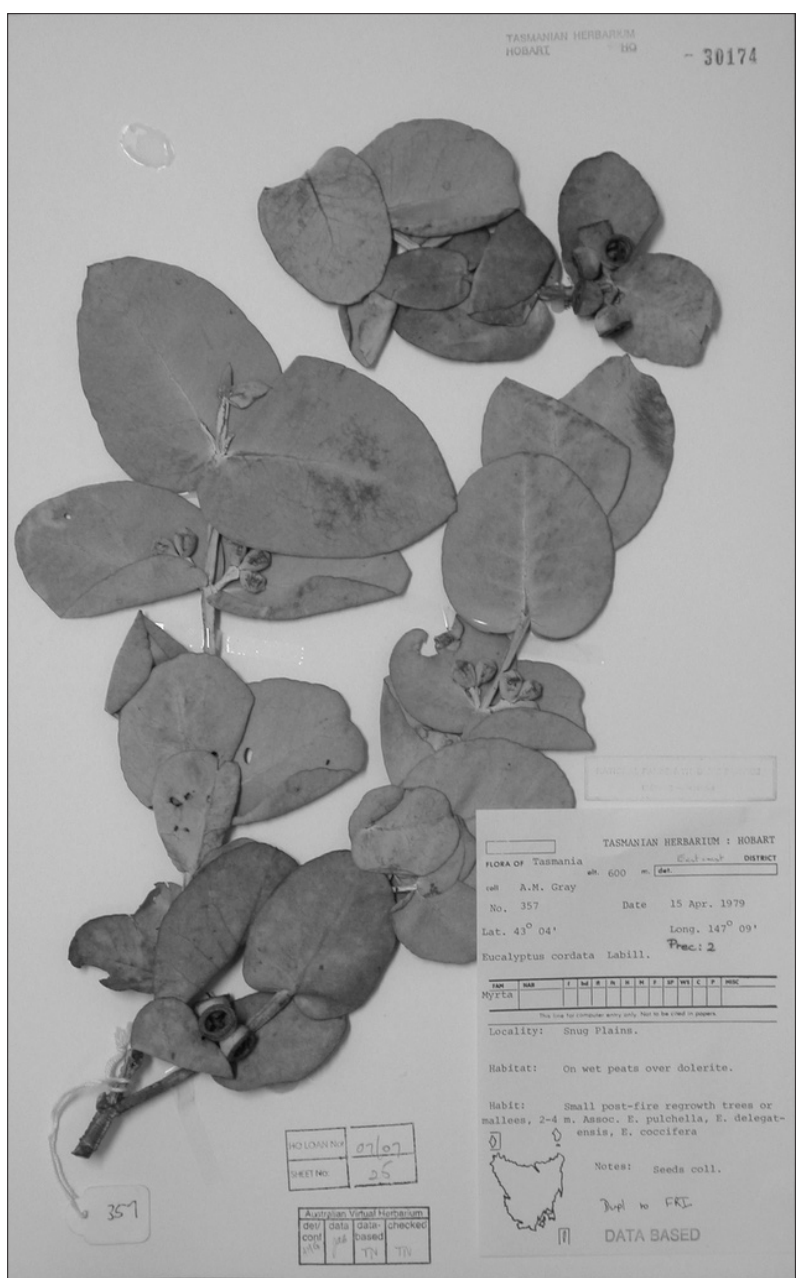

PLATE 3

Holotype of Eucalyptus cordata subsp. quadrangulosa (A.M. Grey 357). usually bi-ribbed; opercula smooth, pileate, $2-5 \mathrm{~mm}$ long. Fruits cupular to truncate-globose, usually bi-ribbed, 10-12 $(-13) \mathrm{mm}$ long $\mathrm{x} 11-14(-15) \mathrm{mm}$ wide, waxy at first; disc broad, descending; valves rarely 3 , usually 4 , to rim level.

\section{Specimens examined}

TASMANIA: Mount Lloyd, Feb. 1941, R. G. Bretts.n. (HO); Mount Lloyd, Aug. 1942, R.G. Brett s.n. (HO); ridge, E of Huonville, May 1945, R.G. Brett s.n. (HO); Herringback, Dec. 1952, W.D. Jackson s.n. (HO); Snug Plains, Margate, Dec. 1952, W.D. Jackson s.n. (HO); Betts Road, NW side of North West Bay River, 1 Aug. 1959, W.D. Jackson s.n. (HO); Moogara area, $1.3 \mathrm{~km} \mathrm{~W}$ of old house on road $3.2 \mathrm{~km}$ from Uxbridge - Moogara junction towards New Norfolk, 13 Nov. 1974, G. Chippendale 1192 \& A.M. Grey (AD, CANB); Moogara, 24 Nov. 1977, M.I.H. Brooker 5779 (AD, HO, MEL, NSW); $13 \mathrm{~km} \mathrm{SW}$ of Glenora Road on road to Mt Lloyd. $100 \mathrm{~m}$ S of junction of road and Leesons Creek, $19 \mathrm{Dec}$. 1977, J.D. Briggs 84 (HO); Leslie Rd, $0.5 \mathrm{~km}$ from junction with Huon Road. Between road and the Levert Rivulet, 3 Jan. 1980, A.M. Grey 458 (CANB, HO); Leslie Rd, 0.5 km from junction with Huon Road. Between road and the Levert Rivulet, 3 Jan. 1980, A.M. Grey 459 (CANB, HO, MEL); Sherwood Hill, 12 Dec. 1988, B. Potts s.n. (HO); on slopes north of Knights Creek, $1200 \mathrm{~m}$ SE of Mt Hull, 15 Dec. 1996, R.B. Schahinger s.n. (HO); Hoopers Hill, Moogara, 10 Feb. 1994, N. McCormick s.n. (HO); Mt Lloyd, SW of New Norfolk, 42 ${ }^{\circ} 0^{\prime} 12^{\prime \prime S}, 146^{\circ} 56^{\prime} 54^{\prime \prime E}, 24$ Feb. 1997, D. Nicolle 1979 (AD, CANB); top of Pelverata Falls, Snug Tiers State Forest, 6 July 1999, A.C. Rozefelds 1405 (HO); Mt Lloyd, SW of New Norfolk, 42 $50^{\prime} 12^{\prime \prime S}, 146^{\circ} 56^{\prime} 54^{\prime \prime E}$, 8 May 2005, D. Nicolle 4940 (AD); foot of Herringback, $43^{\circ} 00^{\prime} 18^{\prime \prime S}, 147^{\circ} 08^{\prime} 44^{\prime E}, 25$ March 1997, A.M. Buchanan 14505 (HO); Lesley Vale Road, c. 1 km from Huon road junction, 29 Jan. 1981, A.M. Grey 543 (AD).

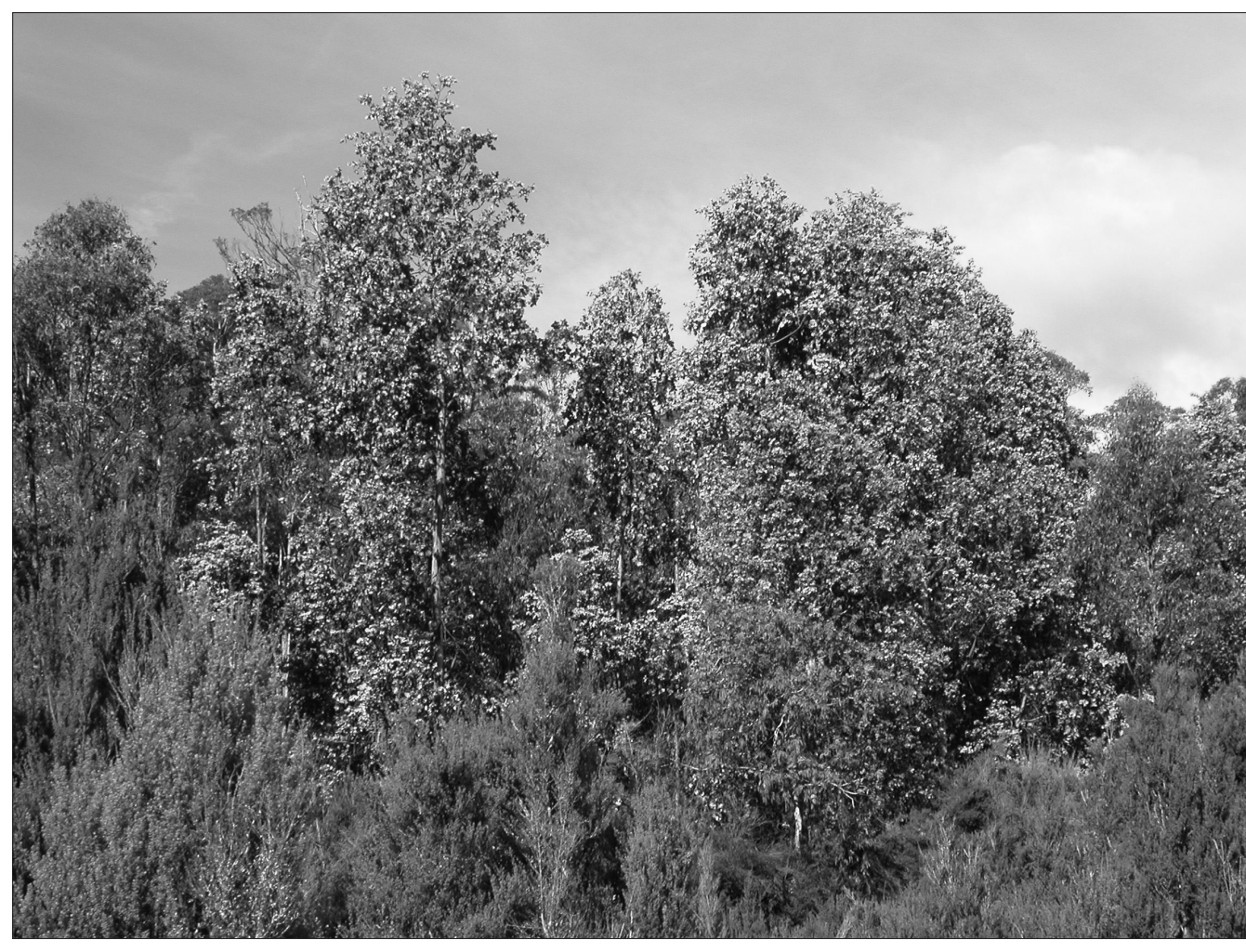

\section{PLATE 4}

Habit and habitat of Eucalyptus cordata subsp. quadrangulosa (Mt Lloyd, SW of New Norfolk, D. Nicolle 4940). 


\section{Distribution and habitat}

Endemic to southeastern Tasmania, and centred in the Wellington Range area, extending northwest to Mt Lloyd and Moogara and south to Snug Plains. The subspecies is most prolific on Snug Plains, but is also known from approximately nine populations elsewhere, over a maximum linear range of approximately $45 \mathrm{~km}$ (fig. 1).

Eucalyptus cordata subsp. quadrangulosa grows in subalpine sites (400-700 m altitude) in wet sclerophyll forest on poorly-drained clay-loams, often on the margins of largely treeless swampy sites dominated by Leptospermum sp. (tea tree) or Gahnia grandis (sedge grass) (pl. 4). Associated eucalypts include E. dalrympleana, E. delegatensis, E. globulus, E. johnstonii, E. obliqua, E. regnans and E. urnigera. The subspecies tends to occur at higher altitudes having a higher and more reliable rainfall and on more poorly-drained soils than those occupied by subsp. cordata.

\section{Conservation status}

Approximately ten populations consisting of at least 7000 individual plants are known. The Snug Plains population is the most extensive, consisting of at least $5000+$ individuals (Potts 1988, 1989), while the northwestern Mt Lloyd and Moogara populations each consist of less than a few hundred individuals.

Eucalyptus cordata subsp. quadrangulosa is poorly conserved compared to subsp. cordata, despite total numbers of the former being greater. Most populations occur on privatelyowned land, and the most extensive populations on Snug Plains occur in state forest.

\section{Etymology}

The subspecific epithet is from the Latin quadrangulosus (four-cornered), referring to the quadrangular (square in cross-section) branchlets, which most readily distinguish the new subspecies within the species. The quadrangular branchlets are also unique in $E$. ser. Orbiculares.

\section{Discussion}

In addition to the morphological distinctions, the two subspecies of $E$. cordata differ in habitat preferences and phenology. E. cordata subsp. quadrangulosa tends to occur at higher altitudes having a higher and more reliable rainfall and on more poorly drained soils than subsp. cordata. Cultivation trials of the two subspecies under uniform conditions (Nicolle 2003, Potts 1989) indicate that the morphological differences between the two subspecies are genetically determined and not related to these environmental variables. Flowering in wild populations of subsp. quadrangulosa occurs mainly in spring (cf. subsp. cordata in autumn and winter). Flowering times in cultivation have not been studied.

The quadrangular stems characteristic of $E$. cordata subsp. quadrangulosa are unique within E. ser. Orbiculares, but are a common and conspicuous feature of the juvenile stems of other taxa within E. sect. Maidenaria, including E. ser. Semiunicolores Blakely (five or six taxa, including E. johnstonii) and E. ser. Globulares Blakely (c. 16 taxa, including E. globulus), as well as occurring in some taxa in all other sections in the genus. The occurrence of quadrangular stems and other characteristics in subsp. quadrangulosa that diagnose the subspecies from subsp. cordata may be due to past genetic introgression from a quadrangularstemmed E. sect. Maidenaria taxon. Both E. globulus and E. johnstonii Maiden occur sympatrically with $E$. cordata subsp. quadrangulosa at some localities, and indeed natural hybrids and hybrid swarms involving E. cordata subsp. quadrangulosa and E. johnstonii, and a putative E. cordata $x$ E. globulus hybrid, have been recorded (Potts 1989). A detailed comparison of chloroplast DNA variation across the full ranges of E. globulus and E. cordata (McKinnon et al. 2004) also supports past, recurrent gene flow between E. globulus and both subsp. quadrangulosa and cordata at different mixed populations. However, the possibility of parallel evolution of the quadrangular stem within different series cannot be dismissed.

Eucalyptus cordata subsp. quadrangulosa is often cultivated in Tasmania and occasionally in the cooler and higherrainfall parts of southeastern mainland Australia, where it is grown as an ornamental bushy tree for its crown of persistent greyish or silvery juvenile foliage. E. cordata subsp. quadrangulosa is also known to be cultivated in New Zealand. This subspecies appears to be more susceptible to seasonally dry conditions in cultivation compared to the rarely cultivated subsp. cordata.

\section{Intermediates between the subspecies}

The two subspecies are geographically divided longitudinally, and for the most part occupy different altitudes. There is no indication of a clinal trend in stem shape with altitude, and when the atypical high-altitude population of subsp. cordata at Brown Mountain is excluded, the change in stem shape is stepped with an abrupt change between 400 and $500 \mathrm{~m}$ altitude. A few populations containing notable frequencies of individuals with variable and/or intermediate stem shape occur at the distributional boundary (fig. 1) at both low and high altitudes. The population at Electrona $(140 \mathrm{~m}$ altitude) currently contains individuals with affinities to both subspecies, with a higher frequency of subsp. cordata, while the Leslie Road population $(250 \mathrm{~m})$ contains approximately equal numbers of the two subspecies, and some individuals of intermediate morphology. The population on the summit of Herringback (680 m) was recorded by Potts (1989) as being predominantly but not exclusively subsp. quadrangulosa. Other intermediate specimens may be found at low frequency in other populations.

\section{ACKNOWLEDGEMENTS}

The first author wishes to thank Sally-Anne Davis and Bob Nicolle for accompaniment on field trips in southern Tasmania and Bob Chinnock (State Herbarium of South Australia) and staff at the Tasmanian Herbarium for organising loan material of E. cordata.

\section{REFERENCES}

Briggs, J.D. \& Leigh, J.H. 1996: Rare or Threatened Australian Plants. CSIRO, Australia: 466 pp.

Brooker, M.I.H. 2000: A new classification of the genus Eucalyptus L'Her. (Myrtaceae). Australian Systematic Botany 13: 79-148.

Brooker, M.I.H. \& Kleinig, D.A. 1999: Field Guide to Eucalypts Vol. 1. South-eastern Australia. Second Edition. Bloomings Books, Melbourne: 353 pp.

Brooker, M.I.H. \& Kleinig, D.A. 2006: Field Guide to Eucalypts Vol. 1. South-eastern Australia. Third Edition. Bloomings 
Books, Melbourne: 356 pp.

Brooker, M.I.H., Slee, A.V., Connors, J.R. \& Duffy, S.M. 2002 Euclid, Eucalypts of Southern Australia. Second Edition. CSIRO Publishing, Australia. CD Rom.

Chippendale, G.M. 1988: Eucalyptus, Angophora. In A.S. George (ed.): Flora of Australia. Volume 19, Myrtaceae - Eucalyptus, Angophora. Australian Government Publishing Service, Canberra: $370-371$

Hooker, J.D. 1860 The Botany of the Antarctic Voyage of H.M. Discovery Ships Erebus and Terror in the years 1830-1843, under the Command of Captain Sir James Clark Ross.III. Flora Tasmaniae. Lovell Reeve, London: 781 pp.

McEntee, A.C., Potts, B.M. \& Reid, J.B. 1994: Variation in Eucalyptus barberi L. Johnson \& Blaxell. Papers and Proceedings of the Royal Society of Tasmania 128: 21-30.

McKinnon, G.E., Vaillancourt, R.E., Steane, D.A. \& Potts, B.M. 2004: The rare silver gum, Eucalyptus cordata, is leaving its trace in the organellar gene pool of Eucalyptus globulus. Molecular Ecology 13: 3751-3762.

McKinnon, G.E., Vaillancourt, R.E., Steane, D.A. \& Potts, B.M. 2008: An AFLP marker approach to lower-level systematics in Eucalyptus (Myrtaceae). American Journal of Botany 95: 368-380.

Nicolle, D. 2003: Currency Creek Arboretum Eucalypt Research.
Vol. 2. D. Nicolle, Adelaide: 81 pp.

Nicolle, D. 2006: Eucalypts of Victoria and Tasmania. Bloomings Books, Melbourne: 310 pp.

Potts, B.M. 1988: The distribution and type locality of Eucalyptus cordata Labill. - an historical account. Papers and Proceedings of the Royal Society of Tasmania 122(2): 31-38.

Potts, B.M. 1989: Population Variation and Conservation Status of the Rare Tasmanian Endemic, Eucalyptus cordata. Tasmanian Forest Research Council Inc., Hobart, Tasmania: $140 \mathrm{pp}$

Pryor, L.D. 1981: Australian Endangered Species: Eucalypts. Special Publications No. 5. Australian National Parks and Wildlife Service: $140 \mathrm{pp}$.

Slee, A.V., Brooker, M.I.H., Duffy, S.M. \& West, J.G. 2006: Euclid, Eucalypts of Australia. Third Edition. CSIRO Publishing, Australia: CD Rom.

Williams, K.J. \& Potts, B.M. 1996: The natural distribution of Eucalyptus species in Tasmania. Tasforests 8: 39-165.

Wiltshire R. \& Potts B. 2007: EucaFlip. School of Plant Science, University of Tasmania and Cooperative Research Centre for Forestry: Pamphlet sheet.

(accepted 1 April 2008) 